\title{
UMA NOVA REFLEXÃO SOBRE \\ OS FUNDAMENTOS DA ÉTICA
}

Goffredo da Silva Telles Jr. 
I

Algumas revelações recentes da Física e da Biologia nos impõem uma nova e arejada reflexão sobre os fundamentos da Ética.

A partir da descoberta de que o surgimento da vida e o advento dos seres de que o homem descende resultaram de um processo de organização de determinados elementos da matéria, somos conduzidos à conclusão de que 0 comportamento moral constitui, por assim dizer, o requinte a que chegou o movimento que anima, desde sempre, todas as cousas do Universo.

De fato, o chamado Mundo Ético, aos olhos sem preconceitos do cientista de nossos dias, não se mostra mais como um mundo separado, destacado e apartado, um mundo de natureza especial. Pelo contrário, ele se apresenta como um estágio da natureza única.

É digna de nota a observação de que a unidade da substância, que é um princípio filosófico de civilizações antiqüissimas, parece patentear-se agora, como corolário do que vem sendo comprovado nos laboratórios da Física Quântica e da Citologia moderna.

Tudo nos vai levando à certeza de que a ordenação ética é uma parte da própria ordenação universal. Ou, em outras palavras, tudo nos convence de que ela é, simplesmente, a ordenação universal no setor humano.

Segundo as novas concepções, a Ética se insere na harmonia do Universo, embora dela emerja, como apurada elaboração do mais evoluído dos seres.

Sobre tal assunto é que nos propomos tecer as seguintes reflexões.

A ordenação ética recebe, muitas vezes, o nome de Moral.

De duas maneiras, pode a ordenação moral ser entendida. Pode ser entendida como a ordenação ideal para a ativi- 
dade do ser humano; e pode ser entendida como a ordenação efetivamente estabelecida pelos usos e costumes.

A ordenação ideal é a ordenação considerada perfeita, ou seja, aquela idealizada ordenação que seria capaz de conduzir o homem para a sua perfeição.

A idéia de perfeição exige um esclarecimento.

A perfeição de um ser não é a perfeição absoluta, que constitui outra cousa. A perfeição de um ser é o seu estado de concluído, dentro da ordem ou categoria a que esse ser pertence.

Perfeito é aquilo que está feito, é que está feito plenamente, completamente.

Perfeito é o ser que terminou seu perfazimento, e que, portanto, possui tudo que lhe convém, tudo que lhe é próprio. É o ser acabado, o ser na plenitude de seu tipo. O ser que satisfez a aspiração de domínio de suas formas ideais.

Perfeito é o ser investido nas formas que o definem.

Ora, cada cousa é definida pela sua natureza.

A natureza de uma cousa consiste naquilo que uma cousa é essencialmente. Consiste, em suma, na essência da cousa. E a essência de uma cousa é aquilo pelo que uma cousa é o que ela é, e se distingue de todas as outras.

A perfeição do ser humano seria o homem na plenitude de seu tipo ideal. Seria o homem verdadeiro, ou seja, o ser que satisfizesse a aspiração de domínio das formas humanas ideais. Seria o homem que correspondesse à sua definição essencial. Seria, portanto, o homem realizado de acordo com a sua natureza.

\section{III}

A vista do que acaba de ser dito, a ordenação ideal para a atividade livre do ser humano é a que leva o homem a ser a plena e perfeita realização de sua natureza.

A natureza, pois, considerada como essência do ser humano, é o supremo critério da Moral. 


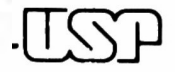

A Moral manda seguir a natureza. Este mandamento significa agir de acordo com a ordem que leva o homem a ser completamente homem. A isto, em suma, se reduz a Moral inteira.

Quando o homem segue a sua natureza, ele se distingue dos demais seres, porque está agindo de acordo com sua própria essência que é, precisamente, o que o faz homem, e o diferencia dos outros animais.

Quando o homem segue a sua natureza, ele tende para o seu perfazimento, dentro da ordem ou categoria a que o homem pertence. Ele tende a ser cada vez mais homem.

Todas estas afirmações, porém, levantam uma questão crucial, que se exprime numa série de perguntas. Qual é o tipo ideal de homem? Quais são as formas humanas ideais? Onde se acha delineado tal tipo? Onde se encontram tais formas? A que se referem, exatamente, as expressões natureza e essência do ser humano? Qual é, enfim, a definição essencial de homem?

As respostas a estas perguntas pressupõem algumas verificações preliminares.

\section{IV}

A primeira verificação é a de que o fenômeno da vida, no ser humano, não se diferencia, em seus elementos físicos, do fenômeno da vida, nos demais organismos. No homem, no elefante e no protozoário; na alga, na violeta e no jequitibá, a oficina profunda da vida é sempre a mesma: a mesma, em sua estrutura; a mesma, em seu funcionamento.

$O$ instrumental da célula única de uma ameba é o mesmo instrumental da célula de uma árvore ou de uma flor, de uma lesma ou de um leão, de um paquiderme ou de um Miguel Angelo.

As operações essenciais das células de toda a biosfera - tanto da biosfera animal, como da biosfera vegetal - se repetem com impressionante monotonia (Jacques Monod, "O Acaso e a Necessidade" Cap. III e VI). 


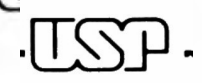

A segunda verificação é a invariância característica dos seres vivos, ou seja, o caráter intensamente conservador dos organismos.

Algumas estruturas chegaram a atravessar muitos milênios sem alteração apreciável. A lígula, por exemplo, é verme que não parece ter sofrido alteração nestes últimos $450 \mathrm{mi}-$ Ihões de anos. A ostra, servida nos restaurantes de hoje, é a mesma ostra de 150 milhões de anos atrás.

A própria célula atual, a célula moderna do reino animal e do reino vegetal, com sua complexissima estrutura e prodigioso funcionamento, já existia, sem grandes diferenças, há dois ou três bilhões de anos.

A terceira verificação é a de que, na longa história dos seres vivos, mutações inumeráveis violentaram a profunda tendência conservadora dos seres vivos, quebraram a persistente invariância da biosfera, e foram transformando os organismos.

Cada mutação aparelhou melhor um organismo, para superação das vicissitudes do ambiente, ou o desfalcou de meios de que já dispunha, para sua preservação.

Sempre que a mutação foi favorável, o organismo, em que ela se operou, adquiriu novos característicos, que colaboraram para a sua sobrevivência. $\mathbf{O}$ organismo ficou mais adaptado ao ambiente em que vivia. E seus descendentes herdaram as qualidades que a mutação Ihe conferiu.

Sempre que a mutação foi desfavorável, o organismo perdeu meios com que já contava para sua preservação. Tornou-se mais vulnerável às adversidades do ambiente. $E$ seus descendentes, mal-adaptados às circunstâncias em que viviam, herdaram essa deficiência.

Na prova inclemente da vida, a que a ordem cósmica sempre submeteu os organismos, só lograram aprovação, só conseguiram impor seus resultados, as mutações que, ao menos, não reduziram a coerência entre os desempenhos do modificado organismo e os objetivos para os quais ele tendia. 
E só alcançaram verdadeiro sucesso as mutações que realmente reforçaram a mencionada coerência, ou, melhor, as que enriqueceram o organismo de poderes novos.

Com o passar do tempo, os organismos desajustados foram sendo destruídos pelas forças adversas. Aos poucos, desapareceram.

Somente venceram, permaneceram e proliferaram os organismos que tiveram as propriedades necessárias para sua adaptação a seus respectivos ambientes $e$, por conseguinte, para a consecução de seus objetivos.

Sucumbiram os inadaptados, preservaram-se os adaptados. $A$ isto se reduziu o processo pelo qual, há 3 bilhões de anos, se foi realizando a triagem impiedosa, de que resultou a seleção natural das espécies.

\section{V}

A invariância fundamental da biosfera, o extraordinário fenômeno das mutações e o processo da seleção natural são as 3 realidades que se conjugam para formar, em cada célula da biosfera, um patrimônio genético.

Um patrimônio genético é um conjunto de genes.

Os genes são as entidades de que se constitui o ácido desoxiribonucléico, ou DNA, no núcleo das células. Tais entidades são responsáveis pela produção das proteínas de um organismo.

O processo de fabricação das proteinas se realiza em rigorosa conformidade com as informações, ou mensagens, expedidas pelos genes.

O que interessa agora salientar é que as células são o que as suas proteinas as fazem ser. Elas são, em verdade, a expressão de suas proteínas. Sua estrutura, suas propriedades, seu desempenho são determinados pelas proteínas que elas próprias sintetizam.

Pode-se dizer que a sorte da célula depende da eficiência de suas proteinas. Se suas proteinas forem defeituosas 


\section{TSF}

ou insuficientes, a célula não poderá exercer suas especificas funçőes. Será uma célula inapta, incapacitada para o exercício de suas atividades vitais. Em conseqüência, não tendo possibilidade de sobrevivência, caminhará para a sua extinção.

Do patrimônio genético de um organismo multicelular, dependem a qualidade e a especificidade de suas proteínas. Da qualidade e especificidade de suas proteínas, dependem a natureza e conseqüentes funções de suas células. Da atuação de suas células, dependem a estrutura e o desempenho de seus tecidos e de seus órgãos. Da estrutura e do desempenho de seus tecidos e órgãos,dependem os traços físicos e as aparências, as tendências e as inclinações, as faculdades e as atuações, a sorte e o destino do organismo inteiro.

Os genes são as primeiras unidades de comando, em todos os seres vivos. São as moléculas mestras da matéria viva. São os condutores da atividade orgânica, em toda a escala biótica, desde a ameba até o homem.

"Os genes governam os organismos", dizem os biólogos.

'De seus respectivos patrimônios genéticos, dependem os seres vivos, para a sua adaptação ou desadaptação ao meio em que vivem. Dessa adaptação ou desadaptação, depende sua sobrevivência ou seu exterminio.

As espécies e variedades que se comportam bem se adaptam, se conservam e evoluem. As que se comportam mal se desadaptam e acabam por desaparecer. Tais são as conseqüências inexoráveis do teste da vida, a que se deu o nome de seleção natural.

Há, pois, uma discriminação genética fundamental entre bons e maus comportamentos. De acordo com ela, são bons os comportamentos que asseguram a sobrevivência das espécies; são maus os que levam a seu extermínio.

No nivel da espécie humana, não é possivel deixar de ver, nessa primeira discriminação, feita pela mãe natureza, a remota fonte dos códigos éticos. 


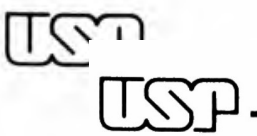

Tais observações, porém, exigem complementação rigorosa.

Antes de tudo, é necessário salientar que um patrimônio genético não é nunca uma entidade isolada, um material separado do mundo.

Os patrimônios genéticos sofreram as moldagens e as triagens que o mundo lhes impôs, por meio de mutações e seleções naturais. $E$, em seu estado atual, têm um desempenho que depende não só deles mesmos, mas, também, de fatores circunstanciais do ambiente em que se encontram.

Um mesmo patrimônio genético atua de maneiras diferentes em circunstâncias diferentes. Fatores ambientais interferem em muitas manifestações de um patrimônio genético. Assim, um ser vivo pode crescer mais, ou crescer menos, em razão do tipo de alimentação recebida; pode ser mais ágil ou menos ágil, conforme o treinamento a que se submeteu; pode ser mais apto para a vida ou menos apto, em razão da educação ou do ensino que lhe tenha sido ministrado.

A mesma pessoa, dotada de um patrimônio genético que lhe confere, por exemplo, uma acentuada inclinação ou predisposição para atividades que exigem previsão e planejamento, poderá, num ambiente propício, chegar a ser campeã mundial de xadrez; em outro ambiente, talvez se limite a ser uma boa jogadora de um clube local; e, em ambiente totalmente desfavorável para a prática do xadrez, poderá nem sequer saber da existência desse jogo.

Um homem, conforme as circunstâncias de sua vida, pode ser campeão de ciclismo; pode ser um ciclista comum, e pode nunca ter andado de bicicleta.

Evidentemente, o patrimônio genético, por si só, não decide a sorte de um ser vivo.

É certo que ninguém será campeão mundial de xadrez ou de ciclismo se seu patrimônio genético não lhe der uma 
especialíssima predisposição para esses tipos de atividade. Mas poderá alguém possuir essa especialíssima predisposição genética, e não ser campeão de cousa nenhuma.

Um patrimônio genético, situado dentro de sua conjuntura ambiental ou mesológica, se chama genótipo.

O genótipo de uma pessoa não é o simples patrimônio genético dela. $\dot{E}$, isto sim, o patrimônio genético em interação com os agentes mesológicos a que a pessoa está efetivamente submetida.

Um genótipo produz manifestações de duas espécies. A primeira é a das manifestações rigidamente determinadas pelos genes, como, por exemplo, a do grupo sangüíneo do animal. A segunda espécie é a das manifestações influenciadas pelo meio ambiente, e muitas vezes, dele dependente, como, por exemplo, as habilitações circunstanciais para os misteres da existência.

Cada genótipo tem sua própria norma de reação, isto é, seu próprio modo normal de se manifestar, em razão dos agentes da conjuntura circunstancial em que o genótipo atua.

Essa norma de reação, como se vê, resulta das relações entre um patrimônio genético e seu meio ambiente.

O conjunto de manifestações de um genótipo se chama fenótipo.

Cumpre salientar que o patrimônio genético não determina, de maneira concreta, cada modalidade dos seres, cada uma de suas atitudes dentro do mundo, cada ação que vai praticar. Não é o fator decisivo e único do desabrochamento, no decurso da vida, daquele tipo humano, geneticamente fixado. Não é o que impõe os modos de aproveitamento, na prática do dia-a-dia, das aptidões, potencialidades e tendências da herança celular.

Da interação de equipamentos genéticos com fatores mesológicos,dependem, por exemplo, a estatura, o peso, a pigmentação da pele, a saúde, a força, a longevidade, e, às 


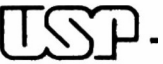

vezes, até os pendores da inteligência e o tipo de temperamento das pessoas. Dessa interação, depende, também, a mentalidade e os modos de ser dos agrupamentos humanos.

Sim, é verdade, os genes governam os organismos; mas os governam com submissão às imposições do ambiente.

Os genes não selam o destino, disse Dobzhansky (" $O$ Homem em Evolução", 4., Iguais mas dissimilares). Em verdade, 0 que os genes fazem é condicionaro destino.

Não há, pois, uma predeterminação dos comportamentos humanos.

Os genes conferem ao homem a sua natureza. Conferem ao homem, por exemplo, uma natureza capaz de aspirações. Mas os genes não determinam cada uma das aspirações humanas. E não são eles que selecionam e deflagram a ação, em cada circunstância da vida.

De fato, os organismos e seus ambientes são interagentes, formando sistemas unidos, que fazem lembrar o que acontece, na Física, com os corpos e seus respectivos campos, que também constituem unidades incindiveis.

O homem e sua interação constituem duas cousas que não se separam. Não existem homens sem interação. A interação dos homens não é algo introduzido de fora, algo de acrescentado, mas é parte integrante e natural de sua estrutura.

Falar, por exemplo, é atividade decorrente de uma predisposição genética. Inegavelmente, no atual estágio da evolução humana, o homem possui uma natureza falante. Mas falar significa falar uma língua. Ora, as diversas línguas pertencem aos ambientes em que se desenrola a vida humana. Só podem ser faladas se forem ensinadas e aprendidas. Logo, na atividade de falar, uma predisposição genética interage com agentes ambientais.

Inumeráveis são os ambientes da vida humana. Alguns são impostos ao homem, outros são escolhidos por ele. Alguns são o refúgio do homem, outros são a conjuntura prefe- 
rida. E entre o ambiente péssimo e o ambiente ótimo para cada personalidade, existe uma infinidade de ambientes intermediários.

Nem sempre tem o homem a possibilidade de fugir do ambiente que the foi imposto. Mas, no decurso da vida, o homem acaba tendendo a passar seus dias, ou suas noites, neste ou naquele ambiente, com estas ou aquelas companhias. E seu comportamento denotará as influências do meio freqüentado.

Na mesma proporção com que o homem escolhe e domina o seu ambiente, ele escolhe e domina seu fenótipo.

$O$ inválido pode submeter-se a tratamento médico, adquirir saúde e voltar ao trabalho. $O$ ignorante pode instruirse, conquistar um lugar ao sol, e passar a exercer novos tipos de atividade. $O$ vadio, o marginal, o delinqüente habitual pode se deixar tocar pelo exemplo, influir pela educação, e, conseqüentemente, pode, um dia, mudar de atitude diante da vida.

Em conclusão, o homem tem a possibilidade de modelar seu fenótipo. Modela-o, é certo, dentro de muitas limitações. Modela-o dentro de seu condicionamento genético. Mas o modela pela sua adaptação a agentes ambientais por ele próprio escolhidos.

"O homem é produto do meio", "O meio faz o homem", costuma-se dizer. E há uma boa parcela de verdade nessas máximas populares. De fato, na produção do fenótipo (que é manifestação do homem), o meio exerce papel importante, porque interage com o genótipo, como foi explicado.

Mas o que é preciso enfatizar é que o meio, em grande parte, é feito pelo homem.

\section{VII}

A moral manda seguir a natureza. Este mandamento, de ordem moral, constitui, como se acaba de ver, um desdobramento de um imperativo de ordem biológica. 
Mas o que é preciso assinalar, com especial atenção, é que o mandamento de seguir a natureza, na ordem moral, não se reduz, simplesmente, ao imperativo de adaptação biológica ao meio, para a sobrevivência da espécie.

Na natureza do homem, algo há que é diferente de tudo quanto existe na natureza dos outros seres vivos.

Dentre os seres vivos, até agora conhecidos, o homem é o ser culminante, a que a energia universal, trabalhando no âmago das cousas, fez chegar a evolução da matéria.

Até o advento do homem, a evolução, na face da Terra era mudança na organização física dos seres. Com o aparecimento do homem, um sistema nervoso central de vários trilhões de neurônios e de quase um quatrilhão de sinapses possibilitou, não só o conhecimento de objetos do Mundo la tradução cerebral desses objetos), mas, ainda, a conversão do próprio conhecimento em objeto de conhecimento. Possibilitou o que se denomina consciência, ou, mais precisamente, consciência reflexiva. E, então, a evolução passou a ser, também, um movimento da própria consciência.

Evolução do homem significa, essencialmente, evolução da consciência. Evolução da consciência que vai emergindo, limitada e estreita, da pura inconsciência material; que luta para romper seu casulo, que se debate contra as paredes de sua prisão de ignorância, que forceja por alcançar a verdade, e que, lentamente, se procura transmudar em consciência plena.

A evolução anterior ao homem, desde a matéria primitiva até o animal racional, se deu sem a participação da consciência. A evolução do ser humano, porém, é marcada pela consciência que dela tem o próprio homem. A evolução deixou de ser uma evolução dentro da ignorância, para ser uma evolução dentro do conhecimento.

No estofo da matéria cósmica, engendrou-se a matéria viva. A matéria viva engendrou a consciência. E a consciência, por sua vez, saindo de seu estado primitivo - estado em 


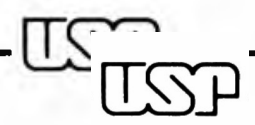

que ela não era muito mais do que instinto - se foi gradualmente desenvolvendo, em formas sempre mais organizadas da matéria viva, até se fazer inteligência racional e espiritual, no ser pensante, propriamente humano.

O homem pertence, em verdade, à ordem ou categoria dos seres inteligentes. Há quem os prefere chamar seres espirituais, designação que parece adequada, porque põe em relevo a diferença entre a inteligência do homem $e$ a inteligência dos outros seres inteligentes. A inteligência do homem inclui, de fato, uma inteligência espiritual, ou seja, um poder de idealização, invenção e planejamento. É uma inteligência formadora de ideais e capaz de aspirações, uma inteligência inclinada para objetivos superiores aos objetivos já atingidos. Uma inteligência inspiradora da vontade.

Em conseqüência, bens espirituais ou ideais hão de existir, como objetos espontâneos da consciência humana. Hão de existir, forçosamente, para o aperfeiçoamento ou perfazimento do homem, isto é, para a realização do homem na plenitude de sua humanidade. Hão de existir, sem dúvida, porque a natureza humana os exige, deles o homem necessita para entrar no domínio das formas que o definem.

Que bens serão estes? Diga-se, antes de mais nada, que são muito numerosos, assumindo as mais diversas formas, em razão das circunstâncias históricas em que vigoram. Podem ser Deus, santidade, virtude, como podem ser conhecimento, ilustração, cultura. Podem se concentrar numa crença; podem convergir para a ciência, podem ser expressões dé beleza. Podem se resumir num ideal de força e poder.

Sem discriminação rigorosa, tais bens podem ser mencionados como bens morais, bens científicos $\mathrm{e}$ bens estéticos. São bens como o respeito à personalidade humana, o reconhecimento da igualdade essencial dos homens, a garantia da liberdade física e da liberdade de manifestar o pensamento, a segurança da justiça, a prática e o reconhecimento da honestidade, a busca da verdade, a criação e a fruicão da beleza. 
Considerados como alvos supremos da ação humana, esses bens talvez possam ser sintetizados em cinco termos: liberdade, justiça, bondade, verdade e beleza.

Nas tábuas dos bens humanos, os espirituais, por força da própria natureza do homem, são bens soberanos. E são soberanos porque são, precisamente, os únicos bens da perfeição especificamente humana.

Para tais bens, o homem tende, por vocação de sua própria natureza. $O$ homem se sente atraido por eles, só por ser homem. Hessen disse que esses bens são os que falam a todos os homens, que a todos conclamam e a todos dirigem seu chamado, pelo simples fato do homem ser homem ("Filosofia dos Valores" Parte I, n. ' IV).

Tais bens são soberanos porque são os bens do humano no homem.

Observe-se que os bens soberanos não se apresentaram, ao espírito dos homens, num só momento da história e num só rol, completo e acabado. Os homens não os inventaram: descobriram-nos. E os foram descobrindo uns após outros, à medida que progrediam no conhecimento de sua natureza. Os bens soberanos se vão iluminando dentro do homem, vão surgindo aos olhos do espirito, como, aos olhos do corpo, aparecem sucessivamente, ao cair da noite, as estrelas do céu (Hessen, "Filosofia dos Valores", Parte I, n. IV).

É patente que os bens soberanos não são sempre os mesmos, em todos os lugares e em todos os tempos. Eles constituem realidades históricas, que se alternam, se substituem, se combinam para formar constelações variáveis, na consciência dos homens.

Os bens soberanos de um ciclo cultural, de uma civilização ou de um simples agrupamento humano podem não ser os bens soberanos de outro ciclo cultural, de outra civilizaçăo ou de outro agrupamento.

Cada ciclo cultural, cada civilização, cada agrupamento se caracteriza, precisamente, por suas respectivas constela- 
çōes de bens soberanos. Tal é a razão pela qual certas épocas são, por exemplo, teocêntricas e místicas, e outras, pragmáticas e utilitaristas.

\section{VIII}

À vista do exposto, uma importante conclusão se impỏe.

Para o homem, o mandamento seguir a natureza significa buscar os bens soberanos.

Buscar os bens soberanos, buscar bens espirituais, é seguir a natureza específica do ser humano; é seguir a natureza determinada pelo patrimônio genético desse ser extraordinário.

Por força de disposições genéticas, a espécie humana, distinguindo-se das outras espécies, encontra as formas de sua perfeição no domínio de bens espirituais.

O homem verdadeiro, que é o homem feito e acabado, na plenitude de seu tipo; o homem perfeito, dentro da ordem ou categoria a que ele pertence, seria o homem que sempre se comportasse em conformidade com seus bem espirituais soberanos. Seria o homem que, sem fraquezas ou desfaleci- . mentos, seguisse os imperativos de sua natureza.

Pois bem, a ordenação destinada a conduzir o homem de acordo com seus bens soberanos é, precisamente, a que se denomina Moral.

Vê-se, pois, que a Moral, como foi afirmado inicialmente, é a ordenação ideal para a atividade livre do ser humano. De fato, a Moral tem por objetivo levar o homem a ser a plena e perfeita realização de sua natureza, isto é, a ser cada vez mais homem, mais completamente aquele ser que a natureza dotou de consciência e espiritualidade.

Mas a inclinação natural do homem para bens espirituais soberanos precisa ser bem entendida.

A causa dessa inclinação se acha, sem dúvida, no patrimônio genético dos seres da espécie humana. $O$ patrimônio genético do homem determina tal inclinação. Mas não deter- 
mina cada um dos bens soberanos, que são objeto dessa mesma inclinação.

0 que os fatos demonstram é que a determinação dos bens soberanos não resulta, somente, de uma inclinação genética para tais bens. Ela depende, também, de inúmeras circunstâncias mesológicas e históricas.

De fato, a formação das constelações dos bens soberanos depende das interações de causas genéticas com fatores do meio ambiente. E este é o motivo de ordenações morais diferentes em povos diferentes e em épocas diferentes.

\section{IX}

Uma certeza resulta de tudo quanto vem sendo exposto.

A Ética e a Biologia se entrelaçam indissoluvelmente. Mais do que isto: essas duas ciências são reciprocamente complementares, porque os bens soberanos do espirito humano desabrocham sobre patrimônios genéticos condicionantes.

Em verdade, o primeiro fundamento das tábuas morais, dos usos e costumes, das ordenações jurídicas legitimas se encontra nos elementos quânticos de que se compõem as moléculas do ácido nucleico, no núcleo das células humanas.

"O homem está inserido no cosmos" disse o biólogo Benedito Ferri de Barros. O homem "faz parte da natureza e por mais que possa agredi-la e agredir-se em suas desvairadas fantasias culturais, não poderá escapar do fato de que, tal como é, está preso a um escudo genético" (Ética e Genética - "A reação científica" artigo no jornal "O Estado de S. Paulo" em 19/01/1983).

Rogério Cézar de Cerqueira Leite, físico, usando de uma expressiva analogia, escreveu: "Quando um animal é concebido (...), seu arranjo genético fica estabelecido na mesma medida em que uma casa comprada já está estruturada. Haverá uma certa liberdade para que o meio, atuando sobre o fi- 
Ihote, molde seu caráter. Mas apenas dentro de certos limites. Na casa comprada, não se pode fazer com que o banheiro se transforme em dormitório, ou vice-versa."... "mesmo no caso da espécie do homo sapiens, as limitações e as potencialidades da natureza biológica, sobre as quais atua 0 meio ambiente, persistem inexoravelmente." ("O louva-adeus e sua noiva barba-azul" artigo no jornal "Folha de $S$. Paulo" de 05/02/1983).

O ser vivo "é a realização de um programa prescrito pela herança", disse o biólogo Brito da Cunha, sintetizando observações de François Jacob, que foi companheiro de Jacques Monod (ambos Prêmio Nobel de Biologia). E continua: "O que Jacob chama de programa é a mensagem contida no material genético, o DNA" "Isso significa que cada um de nós contém no seu DNA um programa que foi testado nas gerações passadas. Os programas são escritos através das gerações." (Coleção da Revista de História, Vol. XLVI História da Ciência - Perspectiva Científica, São Paulo, 1974).

Nesses programas genéticos, encontra-se fixada uma parte considerável daquilo que, tradicionalmente, se chama Ética.

Muito do que os estudiosos da moralidade sempre buscaram explicar por meio dos imperativos da pura consciência humana, a cultura científica dos dias atuais explica pela especificidade cognitiva das proteínas. Explica, portanto, pelo programa inscrito no material genético hereditário.

Diante dessa realidade, não podem mais os filósofos da Moral e do Direito ignorar as contribuições da Biologia, para a correta fundamentação das ordens éticas. E não podem mais os legisladores dispor da sorte humana como se o DNA não existisse.

0 tradicional distanciamento, que sempre foi mantido pelos pesquisadores do Mundo do Espírito e da Cultura, relativamente ao Mundo da Matéria e da Natureza, assim como 
- clássico repúdio à terminologia das Ciências Físicas nas Ciências Humanas, em nome da "dignidade" da Ética e do Direito, é anacronismo avesso ao simples conhecimento das cousas. É manifestação obsoleta, contrária às estruturas da vida.

As revelações da Biologia moderna hão de ter, por força, reflexos importantes nas disciplinas do comportamento humano. À luz dos novos conhecimentos, muitas concepções e muitas leis envelheceram. Em conseqüência, disposições importantes, nas áreas da Moral e do Direito precisam ser conscienciosamente revistas e substituidas. Uma nova Ética precisa ser criada.

Por exemplo, estão a exigir reformulação as definições de crime e de criminoso; de pena e de medida de segurança; de responsabilidade, de culpa e de capacidade. Estão a exigir completa mudança os regimes de tratamento dos infratores e a chamada "tipologia criminal"

Mas o que de mais urgente está a reclamar transformação é a própria idéia da Moral e do Direito Natural, da Justiça e da Eqüidade.

Em virtude das revelações da Biologia, sobre o controle genético dos organismos, o conceito de liberdade e o fundamento da ordem jurídica legítima precisam se desvencilhar dos preconceitos a que estiveram atados. $O$ que precisam é refletir, simplesmente, a realidade da natureza humana.

\section{FICHA CATALOGRÁFICA}

Telles Jr., Goffredo da Silva, "Uma Nova Reflexăo sobre os Fundamentos da Etica" in Revista da Universidade de São Paulo-n. ${ }^{\circ}$, agosto de 1986, pág. 11 a 28. 